\title{
CAUSES OF VARIATION ORDERS IN CONSTRUCTION PROJECTS IN THE GAZA STRIP
}

\author{
Adnan Enshassi ${ }^{1}$, Faisal Arain ${ }^{2}$, Sadi Al-Raee ${ }^{3}$ \\ ${ }^{1}$ Department of Civil Engineering, IUG, Palestine \\ ${ }^{2}$ School of Construction, Southern Alberta Institute of Technology, Canada \\ ${ }^{3}$ Ministry of Transport, Gaza, Palestine \\ E-mails: ${ }^{1} a e n s h a s s i @ g m a i l . c o m ;{ }^{2}$ faisal.arain@gmail.com; faisal.arain@sait.ca \\ Received 20 Nov. 2009; accepted 11 Jun. 2010
}

\begin{abstract}
The maximum project performance would be achieved if the work invariably flows smoothly within time limits and anticipated budget. Variation orders result in time delay, cost overrun, quality defects, and other negative impacts. This is common in construction projects in Gaza Strip. The main objective of this study was to analyze the causes of variation orders in construction projects in Gaza Strip. The causes of variation orders in construction process in Gaza Strip were investigated through questionnaire survey of 36 classified construction companies, 25 consultants and 15 owners. 64 causes of variation orders were identified from literature review. The study results identified the top ten most important factors that include lack of materials and equipment spare parts due to closure, change in design by consultant, lack of consultant's knowledge of available materials, errors and omission in design, conflicts between contract documents, owner's financial problems, lack of coordination among project parties, using inadequate specification for local markets by international consultant, internal politics, and change is specification by owners. In general, the study shows an agreement among owners, consultants and contractors regarding the ranking of the 64 factors causing variation orders. The results also reveal that factors related to consultant are the most important causes of variation orders followed by the factors related to owner. An understanding of the causes of variation orders would be helpful for building professionals in assessing variation orders. Furthermore, the study would also assist professionals in taking proactive measures for reducing variation orders in construction projects. The findings from this study would also be valuable for all construction professionals in general.
\end{abstract}

Keywords: variation orders, construction, contractors, consultant, owner.

\section{Introduction}

Construction contract is a business agreement that is subjected to variability. Contractual clauses relating to changes allows parties involved in the contract to freely initiate variation orders within the ambit of the scope of the work without alteration the original contract (Ndihokubwayo and Haupt 2008). Variation orders involved alteration, addition, omission, and substitution in terms of quality, quantity and schedule of work. The sources of variations include the performance of construction parties, resources availability, environmental conditions, involvement of other parties, and contractual relation. Many time delays, cost overrun and quality defects of a construction can be attributed to variation at various stages of the project (Burati et al. 1992).

Variations and conflicts in a construction projects, at work, and even in our daily lives are very common (Arain and Low 2006). Any addition, deletion, or any other revision to project goals and scope of work are considered to be variation, whether they increase or decrease the project cost or schedule (Ibbs et al. 2001). Sun and Meng (2008) mentioned that a change in construction projects refers to an alteration to design, building works, project programs or project aspects caused by modifications of preexisting conditions, assumptions, or requirements. Ibbs et al. (2007) defined change as any event that results in modification of original scope, execution time, cost and/or quality of work.

The construction sector in Palestine is considered one of the crucial economical sectors. This sector is subjected to a very difficult situation since uprising of $\mathrm{Al}$ Aqsa intifada and the severity of this situation increased after 2006. The frequent and continuous closure of borders crossing leads to severe shortage of construction materials. Many projects are either on hold or subjected to major variations due to shortage of construction materials. The paper aims to analyze the causes of variation orders in construction projects in Gaza strip.

\section{Literature Review}

Ibbs et al. (2007) showed that, there are generally five types of changes: namely, change in scope, differing site condition, delays, suspensions, and acceleration. Hibberd (1986) defined the variation as any changes in the quality or quantity of the works as mentioned or spelled out in a contract documents. Bin-Ali (2008) defined variation 
orders as any deviation i.e., alteration, addition or omission, from the contract with regard to contract drawings, specifications, and/or bills of quantities. Variation order was also defined as the alteration or modification of the design, quality of works, as agreed upon the contract drawings, bill of quantities, and/or specifications (Bin-Ali 2008).

The nature of variation orders can be determined by referring to the reason of occurrence and its effects (Ndihokubwayo and Haupt 2008). Arain and Low (2005) specified two types of variation orders, namely beneficial and detrimental variation orders. Beneficial variations are those that actually help to reduce cost, schedule, or degree of difficulty in the project (Arain and Low 2005). Beneficial variation orders initiated for value analyses purposes to achieve a balance between the cost, functionality and durability aspects of the project to the satisfaction of the client by eliminating unnecessary cost from the project (Ndihokubwayo and Haupt 2008). A detrimental variation order can be defined as the one that negatively impacts the client's value or project performance (Arain and Low 2005). Detrimental variations are those that reduce owner value or have a negative impact on a project (Ndihokubwayo and Haupt 2008).

Although no one can ensure that variation orders can be avoided completely, their occurrence and subsequent waste can be eliminated if their origin and causes are clearly determined (Awad 2001). Lack of effective communication, lack of integration, uncertainty, changing in environment, and increasing project complexity are the drivers of variations in the projects (Arain et al. 2004). Arain and Low (2006) stated that the needs of owner may change in course of design or construction, market conditions may impose changes to the parameters of the project and technological development may alter the design.

Awad (2001) analyzed the variation orders occurrence in a sewer overflow construction projects. The study found that the most frequently project parties generating variation orders were: the engineer generating about $47.1 \%$ of total cost escalation; and the owner generating $43.1 \%$. The study further found that about $55.4 \%$ of the variation orders causing total time extension were generated by the owner group. The results indicated that additional works, design revisions and differing sit conditions were the main reasons of variation orders and had significant impacts i.e., $48 \%$ of the variation orders resulted from additional works, $31.9 \%$ caused by design revisions and $7.8 \%$ caused by differing site conditions. Ndihokubwayo and Haupt (2008) conducted a comparative analysis of cost variability on two completed apartment complex. The study revealed that about $98 \%$ and $95 \%$ of variation orders in each project were generated by the consultant and owner groups, and their values corresponded to $93 \%$ and $92 \%$ of the net total sum respectively.

Ssegawa et al. (2002) investigated the opinion of project parties regarding the frequency of occurrence, causes, and originators of variation orders. The study found that additions and omissions are the most common cause of variations in projects, which represented about
$45.7 \%$ of all variation orders in building projects. Substitutions were considered the third most important cause of variations. The study further revealed that restriction on working conditions (space, access), and replacement of employee were ranked very low occurrence. The main causes of omission related variations were lack of financial, design changes and feasibility of construction. The study results indicated that client and architect caused most of the omission due to financial reasons, design and changes of drawings, and feasibility of construction.

Hsieh et al. (2004) analyzed the causes of variation orders for 90 effective metropolitan public works projects in Taipei. They categorized the main causes of variation orders into two main groups namely: i) administrative needs group which included; change of work rules/regulation, change of decision making authorities, special need for project commission and ownership transfer, and neighborhoods pleading, and ii) construction or technical group which included; planning and design, underground condition, safety considerations, and natural incidents. The study revealed that problems incurred in planning and design stages accounted for the most critical causes of variation orders representing $23.71 \%$ of all causes of variation orders. Safety consideration ranked as the second most important cause of variations contributing about $17.08 \%$ of all causes of variation orders. The study also found that there was a strong correlation between the type of construction and variation orders, thus project characteristics should be considered to streamline the strategy of project management.

Wu et al. (2005) analyzed the causes and effects of 1038 variation orders authorized by project management in a highway construction project in Taiwan. The study found that changes made in response to legislative or policy changes were significant in embankment roads on northern section. It was also revealed through this research that design changes in response to complaints of civilians and geological conditions were significant causes of variation orders. Arain and Low (2006) studied 53 factors that caused variation orders in institutional buildings in Singapore. The study divided these factors into four categories based on the origin of variation orders; i) owner related factors; ii) consultant related factors; iii) contractor related factors; and iv) other factors. The study results indicated that errors and omission in design, change in specification by owner, design discrepancies, change in specifications by consultant, and noncompliance design with governmental regulation considered were the most significant causes of variation orders. The study further revealed that there were a strong correlation between lack of consultant's knowledge of available material and consultant's lack of required data, unavailability of equipment unavailability of skills, differing site condition and honest wrong beliefs of contractor, defective workmanship and contractor's lack of judgment and experience, unfamiliarity with local conditions and complex design and technology, and lack of specialized construction manager and lack of strategic planning.

Variation orders may have several impacts on construction projects such as cost overrun, time overrun, 
quality degradation, and loss in productivity. Arain and Low (2005) studied the effects of variation orders on institutional building project in Singapore. The study found that the most frequent effects of variation orders were; increasing the project cost, additional payment for contractor, progress effect but without delay, completion schedule delay, increase of overhead, and rework and demolition. Awad (2001) analyzed the variation orders of twelve combined sewer overflow projects and found that variation orders caused the cost escalation of $7 \%$ of the original project cost.

Ndihokubwayo and Haupt (2008) stated that variation orders may have direct and indirect cost implications. Direct costs constitute the additional costs incurred to perform the activities of the current variation orders and include: i) resources used including labor, material, and plant to carry out the actual variation orders; ii) increase in overheads-related charges and professional fees; iii) cost of resources that were used to carry out the aborted or substituted works; iv) cost of demolition of aborted or substituted works; and v) cost for resources lying idle before the ordered task restarts. While the indirect costs are those incurred as a result of occurrence of variation orders and include: i) change in cash flow; ii) loss of productivity; iii) cost for redesign and administration of variation order; iv) litigation-related costs in case disputes arise due to variation orders.

Assaf and Al-Hejji (2006) studied the causes of delay in large construction projects in Saudi Arabia, the results of the study indicated that most common cause of delays identified by all three parties of the project was variation orders. Zaneldin (2006) studied the types, causes, and frequency of construction claims in Dubai and Abu Dhabi in the UAE using a data from 124 claims for a variety of projects. The study results indicated that the "variation order" claims were the most frequent type of claims with an important index of $60.5 \%$ and variation order was the most frequent cause of claims with an important index of 55\%. Hanna et al. (1999) developed a statistical model using data from 61 mechanical/electrical projects to estimate the actual amount of labor efficiency lost due to variation orders.

\section{Methodology}

\subsection{Questionnaire Design}

A questionnaire was developed to assess the perception of clients, consultants, and contractors on the relative importance of factors causing variation orders in construction projects in Gaza strip. The questionnaire was divided into two parts. The first part requested general information about the respondent. The second part of questionnaire focused on the causes of variation orders in construction projects in Gaza strip. The respondents were asked to indicate their response on (64) well recognized causes of variation orders as identified by (Arain and Low 2006; Hsieh et al. 2004; Wu et al. 2005; Bin-Ali 2008; Sun and Meng 2008). These causes were categorized into five groups according to the origin of variations i.e., i) Owner related factors, ii) Donor related factors, iii) Design consultant related factors, iv) Contractor related factors, and v) Other factors. The respondents were asked to highlight their recommendations about any other factors that may cause variation orders through open ended questions. The respondents were also requested to identify recommended controls for minimizing variation orders in construction projects. A five point Likert scale ranging from ( 1 very low important to 5 very high important) was adopted to analyze the importance of causes of variation orders.

\subsection{Pilot study}

Before distributing the questionnaire a pilot project was conducted. Ten questionnaires were distributed to expert engineers i.e., projects managers, site engineers/office engineers and organizations managers. The objective of the pilot study was to verify the completeness of questionnaire. The following items are a summary of the major observations based on the pilot study:

1. A donor related factors group should be added to questionnaire which include the following factors: i) financial capability of donor; ii) budget allocated constraints; iii) time constraints; iv) interference of donor in project requirements; and v) relation between donor and client.

2. The following factors were added to different groups: i) lack of coordination between international and local designer; ii) international consultant using inadequate specification to be followed in local conditions; iii) lack of coordination among different various design displaces; iv) inadequate revision and feedback system through design process; v) non clearance of BOQ items; vi) experience of subcontractor; vii) misunderstanding of tender documents by contractor during cost estimate stage; and viii) lack of construction material and equipment spare parts due to siege and closure.

3. Some questions were omitted from questionnaire as suggested by the respondents. These questions were considered impractical or unrealistic with respect to the unique situation of construction projects in the Gaza Strip such as: i) Fast track construction; ii) Honest wrong belief in consultant; and iii) Value Engineering.

4. Some factors were rearranged in order to give more suitable and consistent meaning.

5. Redundant factors were omitted from the questionnaire.

\subsection{Validity test}

To ensure validity of the questionnaire, two statistical tests were applied. The first test is Criterion-related validity test (Spearman test), which measures the correlation coefficient between each item in one Group and the whole Group. To test criterion related validity test, the correlation coefficient for each item of the group factors and the total of the field is achieved. The p-values (Sig.) are less than 0.01 for all results (Table 1), the correlation 
coefficients of each field are significant at $\alpha=0.01$, therefore it can be said that the paragraphs of each field are consistent and valid to measure what it was set for. The second test is structure validity test (Spearman test) that was used to test the validity of the questionnaire structure by testing the validity of each field and the validity of the whole questionnaire. It measures the correlation coefficient between one filed and all the fields of the questionnaire that have the same level of similar scale.

Table 1. Correlation coefficient of each field and the whole of questionnaire

\begin{tabular}{c|l|c|c}
\hline No. & \multicolumn{1}{|c|}{ Field } & $\begin{array}{c}\text { Spearman correla- } \\
\text { tion coefficient }\end{array}$ & P-value \\
\hline 1 & Owner related factors & 0.823 & $0.000^{* *}$ \\
\hline 2 & Donor related factors & 0.753 & $0.000^{* *}$ \\
\hline 3 & $\begin{array}{l}\text { Consultant related } \\
\text { factors }\end{array}$ & 0.853 & $0.000^{* *}$ \\
\hline 4 & $\begin{array}{l}\text { Contractor related } \\
\text { factors }\end{array}$ & 0.703 & $0.000^{* *}$ \\
\hline 5 & Other factors & 0.684 & $0.000^{* *}$ \\
\hline
\end{tabular}

** correlation is significant at $\alpha=0.01$

\subsection{Sampling Method}

The target groups in this study are owners, contractors and consultants. According to the Palestinian Contractors Union in Gaza strip, there are 215 contractor organizations. According to the Engineers' Association in Gaza strip, there are 41 consultant offices. Number of owners is determined as 30 owners in Gaza strip. Kish (1995) showed that the sample size can be calculated as following equation for $90 \%$ confidence level (Arain and Low 2006):

$$
n=\frac{n^{\prime}}{\left[1+\left(\frac{n^{\prime}}{N}\right)\right]},
$$

where: $N$ - total number of population; $n$ - sample size from finite population; $n^{\prime}$ - sample size from infinite population $=S^{2} / V^{2}$; where $S^{2}$ is the variance of the population elements and $\mathrm{V}$ is a standard error of sampling population (Usually $\mathrm{S}=0.5$ and $\mathrm{V}=0.1$ for $90 \%$ confidence interval).

The minimum sample size is 23 for contractors, 15 for consultants, and 14 for owners.

The sampling method used in this study was convenience and snowball sampling. This sampling comes under the class of non-probability sampling techniques. The sample elements are identified by friends and through the referral networks. This method of sampling is preferred when it is difficult to get response from sample population selected at random (Sekaran 2000). One hundred questionnaires were distributed to the potential respondents at all level in the organizations within a construction industry. 50 questionnaires were distributed to contractors, 30 to consultants, and 20 to owners. Of the one hundred distributed, 76 questionnaires were returned that include 36 from contractors (72\%), 25 from consultants $(83 \%)$, and 15 from owners $(75 \%)$.

\subsection{Calculating of Relative Importance of Factors}

The Relative Important Index (RII) method was adopted for similar studies to determine the relative importance of various factors (Sambasivan and Soon 2007). The RII method adopted for this study to determine the relative importance of the various causes of variation orders based on responses from various groups; contractors, consultants, and owners. The five point scale ranged from 1 (very low important) to 5 (very high important) was adopted and transform to relative importance index using the following equation:

$$
R I I=\frac{\sum W}{A \times N},
$$

where: $W$ is the weight given to each factor by the respondents and ranges from 1 to $5 ; A-$ the highest weight $=5 ; N=$ the total number of respondents.

The RII was used to rank the different causes of variation orders in order to cross-compare the relative importance of the factors as perceived by the three groups of respondents. The RII is also used to rank the groups of questionnaire (owner-related, donor related, consultant related, and contractor related factors) by calculating the average of relative importance index of all factors in the group.

\section{Results and Analysis}

\section{Part one: General Information}

The respondents' profile is presented in Table 2.

Table 2. Respondents' profile

\begin{tabular}{lcc}
\hline \multicolumn{1}{c}{ General information } & Frequency & Percent \\
\hline Type of organization & 36 & \\
Contractor & 25 & 37.4 \\
Consultant & 15 & 19.7 \\
Owner & & \\
\hline Field of work for organization & 63 & 82.9 \\
Buildings & 43 & 56.6 \\
Infrastructure & 20 & 26.3 \\
Others & & \\
\hline Classification for contractor & 19 & 52.8 \\
First & 11 & 30.6 \\
Second & 3 & 8.3 \\
Third & 3 & 8.3 \\
Fourth & & \\
\hline Number of working years experience & 10 & 13.2 \\
1-5 years & 20 & 26.3 \\
6-10 years & 24 & 31.5 \\
11-15 years & 22 & 29 \\
More than 15 years & & \\
\hline Job title for respondent & 28 & 36.8 \\
Project manager/deputy & 22 \\
Organization manager/deputy & 28.9 \\
Site engineer & 17 & 22.4 \\
Others & 9 & 11.9 \\
\hline Value of executed projects in the & & \\
last 10 years & 13 & 36.8 \\
1 - less than 20 million USD & 18 & 28.9 \\
2 - less than 5 million USD & 20 & 22.4 \\
5 - less than 10 million USD & 25 & 11.9 \\
More than 10 million USD & & \\
\hline
\end{tabular}


Table 3. RII and Ranks of the top ten most important factors

\begin{tabular}{|c|c|c|c|c|c|c|c|c|}
\hline \multirow{2}{*}{ Factor } & \multicolumn{2}{|c|}{ Contractor } & \multicolumn{2}{|c|}{ Consultant } & \multicolumn{2}{|c|}{ owner } & \multicolumn{2}{|c|}{ Over all } \\
\hline & RII & Rank & RII & Rank & RII & Rank & RII & Rank \\
\hline $\begin{array}{l}\text { Lack of construction materials and equipment } \\
\text { spare parts due to closure and siege }\end{array}$ & 0.878 & 1 & 0.867 & 1 & 0.929 & 1 & 0.884 & 1 \\
\hline Change in design by consultant & 0.861 & 2 & 0.830 & 2 & 0.886 & 2 & 0.856 & 2 \\
\hline $\begin{array}{l}\text { Lack of consultant's knowledge of available } \\
\text { materials and equipment }\end{array}$ & 0.828 & 4 & 0.815 & 3 & 0.857 & 4 & 0.829 & 3 \\
\hline Errors and omission in design & 0.833 & 3 & 0.782 & 12 & 0.871 & 3 & 0.824 & 4 \\
\hline Conflicts between contract documents & 0.811 & 6 & 0.792 & 8 & 0.857 & 4 & 0.814 & 5 \\
\hline Owner's financial problems & 0.811 & 6 & 0.810 & 4 & 0.814 & 12 & 0.811 & 6 \\
\hline Lack of coordination among project parties & 0.800 & 8 & 0.785 & 11 & 0.850 & 6 & 0.805 & 7 \\
\hline $\begin{array}{l}\text { International consultant using inadequate } \\
\text { specification to be followed in local conditions } \\
\text { (e.g. Testing procedure) }\end{array}$ & 0.789 & 10 & 0.789 & 10 & 0.843 & 7 & 0.800 & 8 \\
\hline Internal political problems & 0.828 & 4 & 0.752 & 20 & 0.743 & 24 & 0.786 & 9 \\
\hline Change in specification by owner & 0.767 & 16 & 0.800 & 5 & 0.771 & 19 & 0.779 & 10 \\
\hline
\end{tabular}

\section{Part two: Causes of variation orders}

\section{The Top10 Most Important Factors}

Table 3 shows the rank and the relative importance index for the top ten most important causes of variation orders according to overall respondents and to each party of the respondents.

As shown in Table 3, the top ten most important cause of variation orders in construction projects in Gaza Strip as perceived by all respondents include the lack of construction materials and equipment spare parts due to closure and siege, change in design by consultant, lack of consultant's knowledge of available materials and equipment, errors and omission in design, conflicts between contract documents, owner's financial problems, Lack of coordination among project parties, international consultant using inadequate specification to be followed in local conditions, internal political problems, and change in specification by owner.

The lack of materials and spare parts of equipments because of closure is the most important cause of variation orders in construction projects in Gaza Strip. It was ranked, according to overall respondents, as the first position with RII $=0.884$. Contractor, consultant, and owner also ranked it in the first position with $\mathrm{RII}=0.878$, RII $=$ 0.867 , and RII $=0.929$ respectively. The agreement between all parties endorses the severe situation that the construction industry is suffering from because of siege and closure. The lack of construction materials and spare parts for equipment leads to variations on a construction projects either by omitting some activities that become difficult to perform and do not have major effect on project purpose or by replacing the materials and procedures of construction. This result does not match with literature review due to the difference in situations between Gaza and the other countries.

Change in design by consultant $(\mathrm{RII}=0.856)$ was ranked as the second most important cause of variation orders. Contractor, consultant, and owner ranked this factor $\mathrm{s}$ the second most important cause with relative index $\mathrm{RII}=0.861, \mathrm{RII}=0.83$, and $\mathrm{RII}=0.886$ respective- 1y. This agreement reflects the importance of change in design by consultant as the second most frequent cause of variations in construction projects. The change in design by consultant may come as a response to the lack of information, including civilian complaints that are needed to achieve the project objectives. The reasons for frequent change in design, and the resultant variations, include insufficient time for design process, and unresponsiveness to civilian complaints before starting the construction phase. Therefore, the consultants have to address these issues by changing design during construction phase. This will adversely affect the project and may cause delay in completion. This result is inline with Ssegawa et al. (2002) who found that client and architect caused most of the omission due to financial reasons, design and changes of drawings. It is also inline with $\mathrm{Wu}$ et al. (2005) who found that the most significant cause of variation orders is a change in design due to civilian complaints.

Lack of consultant's knowledge of available materials and equipment is considered the third most important cause of variations orders. It was ranked according to overall respondents in the $3^{\text {rd }}$ position with $\mathrm{RII}=0.829$. All parties (contractor, consultant, and owner) agreed that this factor is one of the top ten most important causes of variation orders. It was ranked by contractor in the fourth position with $\mathrm{RII}=0.82$, ranked by consultant in the third position with RII $=0.815$, and ranked by owner in the fourth with RII $=0.857$. This was expected as the consultant in many occasion utilized junior staff and/or unqualified part time engineers who do not have the required experiences regarding the available materials in local markets. The importance of this factor increased in the Gaza Strip because many construction materials are not available in local market due to siege, so if the consultant does not take this into account during design phase, this may eventually lead to variations during the construction stage.

Errors and omission in design $(\mathrm{RII}=0.824)$ was ranked as the fourth most important cause of variations, as shown in Table 3. There is agreement between cont- 
ractor and owner that it is one of the top ten most important factors causing variation orders in construction process. It was ranked by contractor and owner in the third order with relative index $\mathrm{RII}=0.833$, and 0.871 respectively. Errors and omission in design has always been an important issue because of its adverse impacts on overall construction process. This is because that errors and omissions may lead to delay and loss of productivity. These errors if not rectified during the design phase would eventually appear in a construction phase and initiate variations in order to implement corrective measures. The results as shown in Table 3 identify that there is a disagreement of consultant with owner and contractor regarding the importance of this factor. The consultants ranked this cases as the twelfth important causes of variations with RII $=0.782$. It is not unexpected as the consultants are normally accused for errors and omission. It is therefore normal for consultant to consider this as of less importance than other parties. Another reason for this disagreement could be that the consultant offices targeted have experience more than others professionals, so errors in design were not frequently occurring. The consultant plays a major role in minimizing the errors and omission in design and solving all these problems before construction phase started. This result match with Arain and Low (2006) who found that error and omission in design is the significant cause of variations orders in institutional buildings in Singapore.

As shown in Table 3, conflicts between tender documents was ranked in $5^{\text {th }}$ position with RII $=0.814$. There is an agreement among all parties that this factor is one of the top ten most important causes, it was ranked by contractor, consultant, and owner in $6^{\text {th }}, 8^{\text {th }}$, and $4^{\text {th }}$ positions with RII $=0.811,0.792$ and 0.857 respectively. Conflicts between contract documents may result in misinterpretation of the actual requirements of the project. Conflicts in contract documents frequently occur because of the lack of time that is needed to finalize the design phase in proper way and the inadequate feedback cycle in all design stages (schematic, preliminary, detailed and final) and lack of communication among all project partners and stakeholders. In order to solve the contradiction between tender documents, variation orders have to be initiated. Insufficient details in a contract documents may adversely affect the project implementation and lead to delay in a project completion this results matched with Arain and Low (2006).

Owners financial problems was ranked in $6^{\text {th }}$ position with RII $=0.811$ is the results show an agreement between contractor and consultant to consider it as one of the top ten most important causes of variation orders. It was ranked in the $6^{\text {th }}$ order with RII $=0.811$ by the contractor, and in the $4^{\text {th }}$ order with RII $=0.81$ by the consultant. Most of the owners suffered from financial problems because of the existing situation in Gaza Strip. The financial problems for owner lead him to initiate some variations to the projects in order to reduce the cost to make the budget within his financial capability. The owner disagreed with consultant and contractor in ordering this factor. As shown in Table 3, the owners perceived this as the twelfth important cause of variations with a relatively high relative importance of RII $=0.814$. This $\mathrm{s}$ because the owners realize the importance of this factor but from their point of view there are other factors more important for causing variations. Considering projects in Gaza Strip, most of the projects are usually financed by external donors; eventually the financial capability of owner does not play a major role in causing variations to the project.

Lack of coordination among project parties is ranked by overall respondents in $7^{\text {th }}$ with $\mathrm{RII}=0.805$. It was ranked by contractor in the $8^{\text {th }}$ position with $\mathrm{RII}=0.8$, and ranked by owner in $6^{\text {th }}$ position with RII $=0.85$. This factor appears to be more important for contractor and owner than consultant because the most parties that affected from lack of coordination in construction stage are the contractor and the owner who will be affected by adverse effects of variation on project schedule.

Using of international consultant of inadequate specification for local condition was ranked in $8^{\text {th }}$ position with $\mathrm{RII}=0.8$. It was ranked by contractor and consultant in $10^{\text {th }}$ order with $\mathrm{RII}=0.789$, RII $=0.789$ respectively, and was ranked $7^{\text {th }}$ order with RII $=0.843$ by owner. The international consultant responsible for the consultancy work for big projects is not, in many cases, familiar with local situation. Therefore, he uses international specifications that are inadequate for local conditions. This leads to variations during implementing stage for these specifications to be consistent with local condition.

As shown in Table 3, internal political problems was ranked in $9^{\text {th }}$ position with $\mathrm{RII}=0.786$. There is difference between contractor who ranked it in $4^{\text {th }}$ with $\mathrm{RII}=0.828$ and consultant and owner on the other hand who ranked it in $20^{\text {th }}$, and $24^{\text {th }}$ with $\mathrm{RII}=0.752$, and 0.786 respectively. A lot of funds for projects were withdrawn because of political situation. The contractor is the most effected party of internal political problems.

The study results revealed that the change in specification by owner was ranked in the $10^{\text {th }}$ position with RII $=0.779$ based on overall respondents' feedback. There is a difference among parties toward the importance of this factor, the consultant ranked it in $5^{\text {th }}$ position with RII $=0.8$, while contractor and owner ranked it in $16^{\text {th }}$, and $19^{\text {th }}$ position with RII $=0.767$, and 0.771 respectively. In multi-player environment like construction, change in specifications by owner during the construction phase may need a major variations and adjustment in project planning and procurement activities. This result matched with Arain and Low (2006) who found that change of specifications by owner is one of the top five most important causes of variation orders in institutional buildings in Singapore.

\section{The 10 least important factors}

Table 4 shows the rank and the relative importance index for the ten least important causes of variation orders according to overall respondents and to each party of the respondents. 
Table 4. RII and Ranks of the ten least important factors

\begin{tabular}{l|c|c|c|c|c|c|c|c}
\hline \multirow{2}{*}{\multicolumn{1}{c|}{ Factor }} & \multicolumn{2}{c|}{ Contractor } & \multicolumn{2}{c|}{ Consultant } & \multicolumn{2}{c}{ Owner } & \multicolumn{2}{c}{ Over all } \\
\cline { 2 - 10 } & RII & Rank & RII & Rank & RII & Rank & RII & Rank \\
\hline Contractor's obstinate nature & 0.550 & 64 & 0.610 & 62 & 0.500 & 60 & 0.560 & 64 \\
\hline Experience of subcontractors & 0.567 & 62 & 0.638 & 61 & 0.457 & 61 & 0.569 & 63 \\
\hline Lack of contractor's involvement in design & 0.594 & 60 & 0.680 & 52 & 0.414 & 63 & 0.587 & 62 \\
\hline Technology change from design to implementing stage & 0.606 & 57 & 0.580 & 63 & 0.557 & 59 & 0.588 & 61 \\
\hline Unavailability of skills ( shortage of skilled labor) & 0.567 & 62 & 0.659 & 55 & 0.571 & 58 & 0.598 & 60 \\
\hline Number of project subcontractor & 0.611 & 56 & 0.685 & 50 & 0.443 & 62 & 0.602 & 59 \\
\hline Socio-cultural factors & 0.600 & 59 & 0.750 & 22 & 0.414 & 64 & 0.613 & 58 \\
\hline Contractor's lack of judgment and experience & 0.594 & 60 & 0.648 & 58 & 0.629 & 46 & 0.619 & 57 \\
\hline Contractor's financial difficulties & 0.606 & 57 & 0.676 & 54 & 0.600 & 54 & 0.628 & 56 \\
\hline Contractor's desired profitability & 0.617 & 55 & 0.685 & 50 & 0.586 & 56 & 0.630 & 55 \\
\hline
\end{tabular}

As shown in Table 4, contractor's obstinate nature was ranked in $64^{\text {th }}$ position as the least important causes of variation orders with $\mathrm{RII}=0.560$ as per perceptions of all respondents. All project parties agreed that it was one of the ten least important causes of variation orders. It was ranked by contractor in $64^{\text {th }}$ position with $\mathrm{RII}=0.55$, and by consultant in $62^{\text {nd }}$ order with RII $=0.610$, and in $60^{\text {th }}$ position with RII $=0.5$ by owner. This factor is not important because the variations suggested by contractor are often not accepted by owner or consultant. This result does not match with Arain and Low (2006) findings.

According to the perception of overall respondents, experience of subcontractor was ranked in the $63^{\text {rd }}$ position with RII $=0.659$. There are agreement among all parties that this factor is one of the ten least important factors, it was ranked by contractor, consultant, and owner in $62^{\text {nd }}, 61^{\text {st }}$, and $61^{\text {st }}$ rank with $\mathrm{RII}=0.567,0638$ and 0.457 respectively. In general, the subcontractors have a high experience in their works. Lack of contractor's involvement in design was ranked in $62^{\text {nd }}$ position with RII $=0.587$. There is an agreement between contractor and owner toward this factor, they ranked it in $60^{\text {th }}$, and $63^{\text {rd }}$, position with $\mathrm{RII}=0.594$, and 0.414 respectively. However, the consultant ranked it in $52^{\text {nd }}$ position with $\mathrm{RII}=0.680$. Most of projects in the Gaza Strip are designed by consultant and the involvement of contractor in design is not a professional norm.

Technology change from design to implementing stage seems to be least important, it was ranked by overall in $61^{\text {st }}$ with $\mathrm{RII}=0.588$. There is an agreement among contractor, consultant, and owner in ranking this factor. The time period between the design and construction phase for most projects in the Gaza Strip is not very long. It is therefore that change in technology in terms of construction materials and equipment is not significant. Furthermore, the nature of construction projects in Gaza strip does not require a higher reliance on technology for construction therefore the influence of technology change is limited. Unavailability of skills (shortage of skilled labor) was ranked by overall respondents in $60^{\text {th }}$ position with RII $=0.589$. It was ranked by contractor, consultant and owner in $62^{\text {nd }}, 55^{\text {th }}$, and $58^{\text {th }}$ rank with RII $=0.567$, 0.659 and 0.571 respectively. Most of construction projects in Gaza Strip are not very complicated and can be conducted by available skilled labor in Gaza Strip. Therefore, construction projects have not encountered many variations due to unavailability of skills.

Socio-cultural factors was ranked by overall respondents in $58^{\text {th }}$ position with $\mathrm{RII}=0.613$. There is significant difference between the perception of contractor, consultant and owner toward this factor as shown in Table 4. This is because the consultant takes this factor into consideration during design phase. Contractor's lack of judgment and experience was ranked according to overall respondents in $57^{\text {th }}$ position with $\mathrm{RII}=0.619$. Variations as a result of the lack of contractor's experience are not frequently occurred. This is because of the unique nature of contract process between owner and contractor in Gaza Strip. Contractor's financial difficulties was in $56^{\text {th }}$ position with RII $=0.628$, there is a good level of agreement among all parties toward this factor. Contractor, consultant and owner ranked it in $57^{\text {th }}, 54$ th and $54^{\text {th }}$ positions with RII $=0.606,0.676$ and 0.6 respectively. This agreement reflects that the financial difficulties are not perceived as main cause of variation order. Contractor's desired profitability is ranked according to overall respondents in $55^{\text {th }}$ position with $\mathrm{RII}=0.63$. There is a good level of agreement among all parties toward the importance of this factor as shown in Table 4.

\section{Group analysis}

RII and ranks for each group of causes of variation orders are shown in the Table 5.

\section{Owner related group}

This group of factors was ranked by overall respondents in the second position with $\mathrm{RII}=0.739$. The contractor ranked this group in the $3^{\text {rd }}$ position with $\mathrm{RII}=0.756$, the consultant ranked it in the $1^{\text {st }}$ position with $\mathrm{RII}=0.756$ while the owner ranked it in the $2^{\text {nd }}$ position with $\mathrm{RII}=$ 0.71 . The overall ranking of this group reflects the importance of owner in occurrence of variation orders where the owner plays a major role in causing variations. Any changes in owner's requirements or any financial problems of owner will reflect directly on the project at every phase and may cause variation orders. The differ- 
ences in parties' perceptions toward the importance of

this

group

Table 5. RII and Ranks of the group of causes of variation orders

\begin{tabular}{l|c|c|c|c|c|c|c|c}
\hline \multirow{2}{*}{\multicolumn{1}{c}{ Group }} & \multicolumn{2}{c|}{ Contractor } & \multicolumn{2}{c|}{ Consultant } & \multicolumn{2}{c|}{ Owner } & \multicolumn{2}{c}{ Over all } \\
\cline { 2 - 11 } & RII & Rank & RII & Rank & RII & Rank & RII & Rank \\
\hline Owner related factors & 0.739 & 3 & 0.756 & 1 & 0.710 & 2 & 0.739 & 2 \\
\hline Donor related factors & 0.725 & 4 & 0.709 & 4 & 0.700 & 3 & 0.715 & 4 \\
\hline Consultant Related factors & 0.753 & 2 & 0.730 & 3 & 0.770 & 1 & 0.749 & 1 \\
\hline Contractor related factors & 0.605 & 5 & 0.686 & 5 & 0.590 & 5 & 0.645 & 5 \\
\hline Other factors & 0.759 & 1 & 0.748 & 2 & 0.670 & 4 & 0.738 & 3 \\
\hline
\end{tabular}

are not unexpected. The contractor in many cases is not directly in touch with owner that endorses the perception from the contractor side. The consultant considered that the owner is the major originator of variation orders. This is revealed through the study results where 4 of the most 10 important factors mentioned by consultant are related to owner. This can be explained as the consultant considers that owner is responsible for the all project phases and eventually responsible of any modification needed. The owner also agrees about the importance of factors related to this group in causing variation orders especially those related to financial problems.

\section{Donor related group}

The donor related changes were ranked by overall respondents in the $4^{\text {th }}$ position with $\mathrm{RII}=0.715$. This result reflects that the most factors related to donor had small effects on occurrence of variation orders. This may be due to the insignificant interference of donor in a project phases and that any changes needed by the donor are reflected directly by the owner. The donor does not fund any projects that are not satisfying his guidelines and exceed his financial capability. As the donor allocated necessary fund, he plays a regulator and controller role and his interference in project phases is minimal. Almost all parties agreed that the donor related factors are not so important hence it was ranked in $4^{\text {th }}$ position with $\mathrm{RII}=0.725$ by contractor, in $4^{\text {th }}$ position with RII $=0.725$ by consultant, and in the $3^{\text {rd }}$ position with RII $=0.70$ by owner.

\section{Consultant related group}

This group of factors was ranked by all respondents as the most important group with RII $=0.749$. This result matched with Ssegawa et al. (2002). There are differences among parties in ranking this group. The contractor ranked it in the $2^{\text {nd }}$ position with RII $=0.753$, the consultant ranked it in the $3^{\text {rd }}$ position with $\mathrm{RII}=0.73$, and the owner ranked it in the $1^{\text {st }}$ position with $\mathrm{RII}=0.77$. This ranking seems to be reliable as the consultant believes that owner interference in design impacts the scope of work. Budget allocation, technical requirements as well as fund restriction through donor is more important factors than those related to consultant. The consultant believes that related factors can be overcome and design quality can be improved as these factors are under the control of all project parties. On the other hand, the owner and contractor considered that variations are basically related to technical issues and the consultant is responsible for achieving the optimum quality.

\section{Contractor related group}

This group was ranked in $5^{\text {th }}$ position with $\mathrm{RII}=0.645$, according to overall respondents. There is an agreement among all parties that the contractor related factors group is the least important one. It was ranked in the $5^{\text {th }}$ position with RII $=0.605$ by contractor, $\mathrm{RII}=0.686$ by consultant, and RII $=0.59$ by owner. This result reflects that the contribution of contractor in causing variation orders is minimal as the initiative of any variation is directly related to the approval of client and mainly caused by changes needed by the owner or problems in the design documents. This result matched with Awad (2001) and Ndihokubwayo and Haupt (2008).

\section{Other factors group}

This group was ranked in the third position with RII = 0.738 , according to overall respondents. There are differences among three parties in the ranking of this group. The contractor ranked this group in the $1^{\text {st }}$ position with $\mathrm{RII}=0.759$, the consultant ranked it in $2^{\text {nd }}$ position with $\mathrm{RII}=0.748$, and the owner ranked in the $4^{\text {th }}$ position with $\mathrm{RII}=0.67$. It was revealed that consultant and contractor were more affected by this group than owner hence represented by the study results.

\section{Correlations among parties}

There is a strong correlation between the rank of contractor and owner for the causes of variation orders with correlation coefficient (0.883). However, the correlation between owner and consultant is weakly correlated with correlation coefficient $(0.615)$ and the correlation between consultant and contractor is not strong as shown in the results with a correlation coefficient (0.714). This result reflects the agreement between owner and contractor on the importance of the causes of variation orders. Both of the groups considered that variations were basically related to technical issues and eventually consultant was the main responsible party for occurrence of variation orders. The consultant does not say that these reasons are not important but further considers that the interference of owner in the project contributes significantly in occurrence of variation orders.

\section{Group 1: owner related factors}


Table 6 shows the relative important index and the rank of owner related factors according to each party and to overall respondents.

Owner financial problems is ranked as the most important factor with RII $=0.811$, according to overall respondents. The contractor, consultant, and owner ranked it in the $1^{\text {st }}$ position with $\mathrm{RII}=0.811,0.810$, and 0.814 respectively. Agreement among all parties reflects the importance of this factor as the financial problems for owner has direct effects on the project. This may lead to initiate some major variations to the project in order to reduce the cost to make the project feasible. Change in specification by owner was ranked in the $2^{\text {nd }}$ position with RII $=0.779$, as shown in Table 6 . The results show somewhat agreement among all parties on the importance of this cause. The contractor ranked it in the $3^{\text {rd }}$ position with RII $=0.767$, while the consultant and the owner ranked it in the $2^{\text {nd }}$ position with $\mathrm{RII}=0.800$ and 0.771 respectively. In multi-player environment like construction, change in specifications by owner during the construction phase may need major variations and adjustments in project planning and procurement activities.

Change of project purpose and scope by owner was ranked in the $3^{\text {rd }}$ position with $\mathrm{RII}=0.771$, according to overall respondents. The contractor ranked it in the $6^{\text {th }}$ position with RII $=0.756$, whereas, the consultant and the owner ranked it in $2^{\text {nd }}$ and $3^{\text {rd }}$ position with $\mathrm{RII}=0.8$ and 0.757 respectively. The ranking by contractor is not unexpected as because the contractor may perceive that change in project purpose and scope by owner can affect the scope of contractor's involvement directly limiting the potential opportunities for profits for the contractor.

\section{Group 2: Donors related factors}

Table 6. RII and Ranks of owner related factors

\begin{tabular}{l|c|c|c|c|c|c|c|c}
\hline \multirow{2}{*}{ Owner related factors } & \multicolumn{2}{c|}{ Contractor } & \multicolumn{2}{c|}{ Consultant } & \multicolumn{2}{c|}{ Owner } & \multicolumn{2}{c}{ Over all } \\
\cline { 2 - 11 } & RII & Rank & RII & Rank & RII & Rank & RII & Rank \\
\hline Change project purpose and scope by owners & 0.756 & 6 & 0.800 & 2 & 0.757 & 3 & 0.771 & 3 \\
\hline Change of implementing schedule by owner & 0.667 & 10 & 0.770 & 5 & 0.643 & 9 & 0.696 & 9 \\
\hline Owner's financial problems & 0.811 & 1 & 0.810 & 1 & 0.814 & 1 & 0.811 & 1 \\
\hline Inadequate project objectives & 0.711 & 7 & 0.733 & 8 & 0.737 & 5 & 0.723 & 6 \\
\hline Replacement of material or procedure by owner & 0.767 & 3 & 0.800 & 2 & 0.688 & 6 & 0.762 & 4 \\
\hline Impediment in prompt decision making process & 0.778 & 2 & 0.752 & 7 & 0.740 & 4 & 0.762 & 4 \\
\hline Obstinate nature of owner & 0.683 & 9 & 0.648 & 10 & 0.648 & 8 & 0.665 & 10 \\
\hline Change in specification by owner & 0.767 & 3 & 0.800 & 2 & 0.771 & 2 & 0.779 & 2 \\
\hline Land allocation problems & 0.694 & 8 & 0.762 & 6 & 0.625 & 10 & 0.703 & 8 \\
\hline Inadequate experience of owner's staff & 0.758 & 5 & 0.686 & 9 & 0.671 & 7 & 0.717 & 7 \\
\hline
\end{tabular}

Table 7. RII and Ranks of donors related factors

\begin{tabular}{l|c|c|c|c|c|c|c|c}
\hline \multirow{2}{*}{ Donor related factors } & \multicolumn{2}{c|}{ Contractor } & \multicolumn{2}{c|}{ Consultant } & \multicolumn{3}{c|}{ Owner } & \multicolumn{2}{c}{ Over all } \\
\cline { 2 - 10 } & RII & Rank & RII & Rank & RII & Rank & RII & Rank \\
\hline Financial capability of donor & 0.700 & 4 & 0.722 & 3 & 0.650 & 4 & 0.697 & 4 \\
\hline Budget allocated constraints & 0.756 & 1 & 0.739 & 2 & 0.790 & 1 & 0.752 & 1 \\
\hline Time constraint & 0.728 & 3 & 0.705 & 5 & 0.686 & 3 & 0.715 & 3 \\
\hline Interference of donor in project requirements & 0.700 & 4 & 0.714 & 4 & 0.625 & 5 & 0.687 & 5 \\
\hline
\end{tabular}

Table 7 shows the relative important index and the rank of donor related factors.

Budget allocated constraints was ranked according to overall respondents in the $1^{\text {st }}$ position with $\mathrm{RII}=0.752$. The results show some agreement among all parties owner ranked it in the $1^{\text {st }}, 2^{\text {nd }}$, and $1^{\text {st }}$ position with $\mathrm{RII}=$ $0.756,0.739$, and 0.790 respectively. Sometimes the client and consultant have to initiate variation orders by omitting some activities because of the budget constraints that do not allow any additional fund for improvement in scope and covering the raising prices of materials. Relation between client and donor was ranked in the $2^{\text {nd }}$ position with RII $=0.724$, according to overall respondents. The relation between client and donor plays an important role in initiating variation orders either by allowing additional fund for performing new activities or by putting constraints on fund that may lead to omissions.

\section{Group 3: consultant related factors}

Table 8 shows the rank and the relative importance index for the most five importance factors in consultant related factors group.

Change in design by consultant was ranked according to overall as the most important factor with RII = 0.856 . There is agreement among all parties that this factor is the most important one. The reason for frequent change in design, and the variations that follow it, is that it in proper way and unresponsive to civilian complaints before starting the construction phase so the consultant have to solve that by changing design during construction phase. towards this factor as the contractor, consultant, and the design process is not given the enough time to finalize 


\begin{tabular}{|c|c|c|c|c|c|c|c|c|}
\hline Relation between donor and client & 0.739 & 2 & 0.750 & 1 & 0.760 & 2 & 0.724 & 2 \\
\hline \multirow{2}{*}{ Consultant related factors } & \multicolumn{2}{|c|}{ Contractor } & \multicolumn{2}{|c|}{ Consultant } & \multicolumn{2}{|c|}{ Owner } & \multicolumn{2}{|c|}{ Over all } \\
\hline & RII & Rank & RII & Rank & RII & Rank & RII & Rank \\
\hline Change in design by consultant & 0.861 & 1 & 0.830 & 1 & 0.886 & 1 & 0.856 & 1 \\
\hline Errors and omission in design & 0.833 & 2 & 0.782 & 7 & 0.871 & 2 & 0.824 & 3 \\
\hline Conflicts between contract documents & 0.811 & 4 & 0.792 & 3 & 0.857 & 4 & 0.814 & 4 \\
\hline Lack of coordination among project parties & 0.800 & 5 & 0.785 & 6 & 0.850 & 5 & 0.805 & 5 \\
\hline $\begin{array}{l}\text { Lack of consultant's knowledge of available } \\
\text { materials and equipment }\end{array}$ & 0.828 & 3 & 0.815 & 2 & 0.857 & 3 & 0.829 & 2 \\
\hline
\end{tabular}

Table 9. RII and Ranks of the most five important factors in contractor related factors

\begin{tabular}{l|c|c|c|c|c|c|c|c}
\hline \multirow{2}{*}{ Contractor related factors } & \multicolumn{2}{c|}{ Contractor } & \multicolumn{2}{c|}{ Consultant } & \multicolumn{2}{c}{ Owner } & \multicolumn{2}{c}{ Over all } \\
\cline { 2 - 11 } & RII & Rank & RII & Rank & RII & Rank & RII & Rank \\
\hline Differing site condition & 0.733 & 1 & 0.724 & 2 & 0.729 & 1 & 0.729 & 1 \\
\hline $\begin{array}{l}\text { Unfamiliarity of international contractor with } \\
\text { local conditions }\end{array}$ & 0.706 & 3 & 0.695 & 7 & 0.627 & 7 & 0.687 & 5 \\
\hline Lack of specialized construction manager & 0.689 & 4 & 0.724 & 2 & 0.671 & 3 & 0.697 & 4 \\
\hline Poor procurement process & 0.722 & 2 & 0.724 & 2 & 0.614 & 8 & 0.701 & 3 \\
\hline $\begin{array}{l}\text { Misunderstanding of tender documents during } \\
\text { cost estimate stage }\end{array}$ & 0.678 & 5 & 0.743 & 1 & 0.700 & 2 & 0.704 & 2 \\
\hline
\end{tabular}

Lack of consultant's knowledge of available materials and equipment was ranked as the second most important factor with RII $=0.829$. There is nearly agreement among all parties about the importance of this factor. The utilization of junior staff and/or unqualified part time engineers, who do not have the required experiences regarding the available materials in local market, increased the importance of this factor. Errors and omission in design ranked as the third most important factor with RII $=0.829$. The results show differing perceptions between consultant and other parties. The consultant ranked this factor in $7^{\text {th }}$ position with $\mathrm{RII}=0.782$ while contractor and owner ranked it in the $2^{\text {nd }}$ position with $\mathrm{RII}=0.833,0.871$ respectively.

\section{Group 4: contractor related factors}

Table 9 shows the rank and the relative importance index for the most five importance factors in contractor related factors group.

Differing site condition was ranked according to overall respondents in the first position with $\mathrm{RII}=0.72$. Almost all parties agreed that this factor is the most important as shown in the table. The variation orders may be suggested by the contractor due to differing site condition. This is because differing in site conditions may affect the cost estimation and schedule adversely. Misunderstanding of tender documents during cost estimate stage was ranked as the second most important cause of variations with RII $=0.704$. The results show an agreement between consultant and owner, however, the contractor ranked it in $5^{\text {th }}$ position. The misunderstanding in tender documents does not happen frequently. However, the owner and consultant perceived it as a frequent cause of variations and that the contractor may consider this as an opportunity to suggest variations to omit the low priced activities.

Poor procurement process was ranked according to all respondents in the third position with $\mathrm{RII}=0.701$. Sometimes contractor prices the bid lower than the cost price and eventually relies on potential variation orders to increase the contract price depending on some factors related to owner, consultant and site conditions. The owner differs with consultant and contractor towards the importance of this factor, he ranked it in $8^{\text {th }}$ position with RII $=0.701$. This is because the owner perceives that the lower bid method of awarding is a practical option and poor procurement process is not significantly important in causing variation orders. Lack of specialized construction manager was ranked in the $4^{\text {th }}$ position with RII = 0.697 , according to overall respondents. The lack of specialized construction manager may lead to misunderstanding of tender documents and eventually incorrect pricing. In this case, the contractor may suggest variation orders to increase the price of contract.

\section{Group 5: other factors}

Table 10 shows the relative important index and the rank of contractor related factors according to each party and to overall respondents.

Lack of construction materials and equipment spare parts due to closure and siege was ranked as the most important cause with RII $=0.884$. This shows an agreement among all parties towards the importance of this factor. Internal political problems was ranked in $2^{\text {nd }}$ position with RII $=0.786$. It is observed that funds for projects are withdrawn frequently because of political situation. If the project in construction phase, this may lead to 
change in scope of work and eventually initiate variation orders.

Table 10. RII and Ranks of other factors

\begin{tabular}{l|c|c|c|c|c|c|c|c}
\hline \multirow{2}{*}{ Other factors } & \multicolumn{2}{c|}{ Contractor } & \multicolumn{2}{c|}{ Consultant } & \multicolumn{3}{c}{ Owner } & \multicolumn{2}{c}{ Over all } \\
\cline { 2 - 11 } & RII & Rank & RII & Rank & RII & Rank & RII & Rank \\
\hline Weather conditions & 0.728 & 6 & 0.657 & 8 & 0.586 & 7 & 0.699 & 6 \\
\hline Safety consideration & 0.756 & 5 & 0.667 & 5 & 0.614 & 5 & 0.724 & 5 \\
\hline Change in governmental regulations & 0.706 & 7 & 0.667 & 5 & 0.614 & 5 & 0.687 & 7 \\
\hline Change in economical conditions & 0.800 & 3 & 0.762 & 2 & 0.700 & 4 & 0.768 & 3 \\
\hline Socio-cultural factors & 0.600 & 8 & 0.667 & 5 & 0.414 & 8 & 0.613 & 8 \\
\hline Internal political problems & 0.828 & 2 & 0.752 & 3 & 0.743 & 3 & 0.786 & 2 \\
\hline Unforeseen problems & 0.772 & 4 & 0.686 & 4 & 0.786 & 2 & 0.746 & 4 \\
\hline $\begin{array}{l}\text { Lack of construction materials and equipment } \\
\text { spare parts due to closure and siege. }\end{array}$ & 0.878 & 1 & 0.867 & 1 & 0.929 & 1 & 0.884 & \multirow{2}{*}{1} \\
\hline
\end{tabular}

\section{Conclusions}

The study objective was to analyze the causes of variation orders in construction projects in Gaza Strip. The results indicated that, group of factors related to consultant is the most important group of causes of variation orders in construction projects in Gaza strip. Group of factors related to contractor and donor are the least important groups of causes of variation orders. Among 64 causes of variation orders, the lack of materials and spare parts due to closure is considered as the most important cause of variation orders in construction projects in Gaza strip.

Considering the factors related the consultant, the most important cause of variation orders is change in design by a consultant and the least important variation cause is change in technology from design to implementing stage. Regarding the owner related factors, the most important cause of variation orders is owner's financial problems and the least important variation cause is the obstinate nature of owner. Concerning the donor related factors, the most important cause of variation orders $i s$ budget allocated constraints and the least important variation cause is the interference of donor in project requirements. Considering the contractor related factors, the most important cause of variation orders is differing site conditions and the least important factor is the contractor's obstinate nature.

Considering the other factor group, the most important cause of variation orders is lack of materials and spare parts of equipment due to closure and the least important variation cause is the socio-cultural factors. There is a strong correlation between ranking by owner and contractor while the correlations between the ranking by consultant and owner and consultant and contractor are not considered strong. Siege and closure issue should be considered in the condition of the contract to ease dealing with changes. Strengthening the information flow channels, feedback process, internal and external auditing through all stages of design starting from drafting Term of Reference (ToR) then schematic, preliminary, detailed and issuing tender documents may assist in minimizing changes in design.

The Ministry of Housing and Public Works should establish a comprehensive database that includes unit price, supplier, and specifications. The database should be updated periodically. This will enhance the awareness of consultant regarding the available materials in local and regional markets. Sufficient time should be given for planning and design phase, this will assist in minimizing errors in design, conflicts between tender documents. The project owner should provide a clear scope of work; this will help in minimizing variation orders. The coordination between international and local consultants should be improved in order to reduce issues due to inadequate specifications. An understanding of the causes of variation orders would be helpful for building professionals in assessing variation orders. Furthermore, the study would also assist professionals in taking proactive measures for reducing variation orders in construction projects. The findings from this study would also be valuable for all construction professionals in general.

\section{References}

Arain, F. M.; Assaf, S.; Low, S. P. 2004. Causes of discrepancies between Design and Construction, Architectural Science Review 47(3): 237-249.

Arain, F. M.; Low, S. P. 2005. The potential effects of variation orders on institutional building projects, Facilities 23(11/12): 496-510. doi:10.1108/02632770510618462

Arain, F. M.; Low, S. P. 2006. Developers' Views of Potential Causes of Variation Orders for Institutional Buildings in Singapore, Architectural Science Review 49(1): 59-74.

Assaf, S. A.; Al-Hejji, S. 2006. Causes of delay in large construction projects, International Journal of Project Management 24(4): 349-357. doi:10.1016/j.jproman.2005.11.010

Awad, M. 2001. Analysis and Management of Change Orders for Combined Sewer Flow Construction Projects. Unpublished Dissertation, Wayne State University.

Bin-Ali, A. Z. 2008. Causes and Steps to Minimize Variations in Construction Projects. Unpublished Master Thesis, University Technology Malaysia.

Burati, J. L.; Farrington, J. J.; Ledbetter, W. B. 1992. Causes of quality deviation in design and construction, Journal of Construction Engineering and Management 118(1): 3449. doi:10.1061/(ASCE)0733-9364(1992)118:1(34)

Hanna, A. S.; Russell, J. S.; Gotzion, T. W.; Nordheim, E. V. 1999. Impact of change orders on labor efficiency for me- 
chanical construction, Journal of Construction Engineering and Management 125(3): 176-184. doi:10.1061/(ASCE)0733-9364(1999)125:3(176)

Hibberd, P. R. 1986. Variations on construction contracts. Collins, London.

Hsieh, T.; Lu, S.; Wu, C. 2004. Statistical analysis of causes for change orders in metropolitan public works, International Journal of Project Management 22(8): 679-686. doi:10.1016/j.ijproman.2004.03.005

Ibbs, W.; Wong, C.; Kwak, H. 2001. Project change management system, Journal of Management in Engineering 17(3): 159-165. doi:10.1061/(ASCE)0742-597X(2001)17:3(159)

Ibbs, W.; Nguyen, L.; Lee, S. 2007. Quantified impacts of project change, Journal of Professional Issue in Engineering Education and Project 133(1): 45-52. doi:10.1061/(ASCE)1052-3928(2007)133:1(45)

Kish, L. 1995. Survey Sampling (65th edition). John Wiley and Sons Inc., New York.

Ndihokubwayo, R.; Haupt, T. C. 2008. Uncovering the origins of variation orders, in Proceedings of the $5^{\text {th }}$ Post Graduate Conference on Construction Industry Development, 1618 March 2008, Bloemfontein, South Africa, 88-96.
Sambasivan, M.; Soon, Y. W. 2007. Causes and effects of delays in Malaysian construction industry, International Journal of Project Management 25(5): 517-526. doi:10.1016/j.ijproman.2006.11.007

Sekaran, U. 2000. Research methods for business: a skill building approach. 3rd ed. New York: John Wiley.

Ssegawa, J. K.; Mfolwe, K. M.; Makuke, B.; Kutua, B. 2002. Construction variation: A scourge or a necessity?, in Proceeding of the First International Conference of CIBW107, 11-13 November 2002, Cap Town, South Africa, 87-96.

Sun, M.; Meng, X. 2008. Taxonomy for change causes and effects in construction projects, International Journal of Project Management 27(6): 560-572. doi:10.1016/j.ijproman.2008.10.005

Wu, C.; Hsieh, T.; Cheng, W. 2005. Statistical analysis of causes for design change in highway construction on Taiwan, International Journal of Project Management 23(7): 554563. doi:10.1016/j.ijproman.2004.07.010

Zaneldin, E. K. 2006. Construction claims in United Arab Emirates: Types, causes, and frequency, International Journal of Project Management 24(5): 453-459. doi:10.1016/j.ijproman.2006.02.006

\section{PRIEŽASTYS, LEMIANČIOS PAKEITIMŲ NURODYMUS GAZOS RUOŽO STATYBŲ PROJEKTUOSE}

\section{A. Enshassi, F. Arain, S. Al-Raee}

\section{Santrauka}

Projektas bus efektyviausias, jei darbai vyks nuolatos ir sklandžiai, neviršijant terminų ir numatyto biudžeto. Dèl pakeitimų nurodymų projektas užtrunka, viršijamos sąnaudos, atsiranda kokybès trūkumų ir patiriamas kitoks neigiamas poveikis. Tai būdinga Gazos ruože vykstantiems statybų projektams. Pagrindinis šio tyrimo tikslas - išanalizuoti, kokios priežastys Gazos ruožo statybų projektuose lemia pakeitimų nurodymus. Priežastys, lemiančios pakeitimų nurodymus Gazos ruožo statybų procese, buvo tiriamos atlikus 36 tam tikros kategorijos statybos įmonių, 25 konsultantu ir 15 savininkų apklausą. Apžvelgus literatūrą nustatytos 64 pakeitimų nurodymus lemiančios priežastys. Atlikus tyrimą, buvo nustatyti dešimt svarbiausių veiksnių, įskaitant medžiagų ir atsarginių ịrangos dalių trūkumą dèl uždarymo, projekto konsultanto pakeitimus, nepakankamas konsultanto žinias apie galimas medžiagas, projekto klaidas ir trūkumus, vienas kitam prieštaraujančius sutarties dokumentus, finansines savininko problemas, veiksmų koordinavimo trūkumą tarp projekto dalyvių, tarptautinio konsultanto naudojamas vietinių rinkų neatitinkančias specifikacijas, vidaus politiką ir savininkų pakeitimus specifikacijoje. Apskritai tyrimas rodo, kad savininkai, konsultantai ir rangovai sutaria dèl to, kaip pagal svarbą išsidèsto 64 veiksniai, lemiantys pakeitimu nurodymus. Be to, rezultatai rodo, kad su konsultantu susiję veiksniai yra svarbiausios pakeitimų nurodymų priežastys, o antroje vietoje - su savininku susiję veiksniai. Statybų specialistams suprantant, kokios priežastys lemia pakeitimų nurodymus, tokius nurodymus jiems vertinti būtų lengviau. Be to, tyrimas padètų specialistams imtis aktyvių priemonių, kad statybų projektuose pakeitimų nurodymų būtų mažiau. Šio tyrimo išvados taip pat būtų naudingos visiems statybų specialistams apskritai.

Reikšminiai žodžiai: pakeitimų nurodymai, statybos, rangovai, konsultantas, savininkas.

Adnan ENSHASSI. Professor of Construction Engineering and Management at the Civil Engineering Department at the Islamic University of Gaza. He is a Member/Fellow of a number of international professional institutions in USA and UK. He has over 100 research publications in both International refereed Journals as well as Conferences. H e is the regional editor of the International Journal of Construction Management and at the Editorial Board of the International Journal of Construction Project management. His research interests include safety in construction, productivity improvement, risk management, and Construction and demolition waste management

Faisal Manzoor ARAIN. Has extensive experience of working at management and leadership positions in industry and academia in Pakistan, Saudi Arabia, Singapore and Canada. Dr. Arain has consulted, researched and published widely in the discipline of Project Management and Design and Construction Management. He has over 60 research publications, 4 books, 2 book chapters and numerous professional magazine publications. Dr. Arain serves on editorial boards of several international research journals. Dr. Arain is one of the panel judges for professional awards conferred by PMI, USA. Dr. Arain is currently working as Chair, Construction Project Management with Southern Alberta Institute of Technology (SAIT), Calgary, Canada.

Sadi Ibrahim AL-RAEE. The director of Engineering and Traffic Safety standards in the Ministry of Transport, Gaza. Palestine. He is a member in of Association of Engineers, Gaza. His research interests include the modeling of transporting particularly mode choice modeling and planning of transpiration and infrastructure projects. 